University of Nebraska - Lincoln

DigitalCommons@University of Nebraska - Lincoln

$10-27-2015$

\title{
Land-Use Change Impact on Soil Sustainability in a Climate and Vegetation Transition Zone
}

\author{
K. D. Reitsma \\ Encirca Services
}

B. H. Dunn

South Dakota State University

U. Mishra

Argonne National Laboratory

S. A. Clay

South Dakota State University, sharon.clay@sdstate.edu

T. DeSutter

North Dakota State University

See next page for additional authors

Follow this and additional works at: https://digitalcommons.unl.edu/usdoepub

Reitsma, K. D.; Dunn, B. H.; Mishra, U.; Clay, S. A.; DeSutter, T.; and Clay, D. E., "Land-Use Change Impact on Soil Sustainability in a Climate and Vegetation Transition Zone" (2015). US Department of Energy Publications. 362.

https://digitalcommons.unl.edu/usdoepub/362

This Article is brought to you for free and open access by the U.S. Department of Energy at DigitalCommons@University of Nebraska - Lincoln. It has been accepted for inclusion in US Department of Energy Publications by an authorized administrator of DigitalCommons@University of Nebraska - Lincoln. 


\section{Authors}

K. D. Reitsma, B. H. Dunn, U. Mishra, S. A. Clay, T. DeSutter, and D. E. Clay 


\title{
Land-Use Change Impact on Soil Sustainability in a Climate and Vegetation Transition Zone
}

\author{
K. D. Reitsma, B. H. Dunn, U. Mishra, S. A. Clay, T. DeSutter, and D. E. Clay*
}

\begin{abstract}
A growing world population and climate change are expected to influence future agricultural productivity and land use. This study determined the impact of land-use change on soil sustainability and discussed the factors contributing to these changes. South Dakota was selected as a model system because corn (Zea mays L.) grain prices tripled between 2006 and 2012 and it is located in a climate and grassland/cropland transition zone. High resolution imagery was used to visually determine land uses (cropland, grassland, nonagricultural, habitat, and water) at 14,400 points in 2006 and 2012. At each point, land-use change and the USDA land capability class (LCC) were determined. Over the 6-yr study period, $6.87 \%$ of the grasslands $(730,000$ ha) were converted to cropland, with $93 \%$ occurring on lands generally considered suitable for crop production (LCC $\leq$ IV) if appropriate practices are followed. Converted grasslands, however, had higher LCC values than existing croplands and lower LCC values than remaining grasslands. In addition, $4.2 \%$ of the croplands $(250,000 \mathrm{ha})$ were converted to grasslands, and statewide, 20,000 ha of croplands were converted to grasslands in areas limited by excess water (LCC V). The conversion of grasslands could not be linked to one specific factor and may be related to: (i) a desire to increase financial returns, (ii) changes in the land ownership structure, (iii) technology improvements, (iv) governmental policies, (v) climate change, and (vi) an aging workforce. Research and outreach programs that balance the goods and services of different land uses are needed to maintain sustainable agroecosystems.
\end{abstract}

Published in Agron. J. 107:2363-2372 (2015)

doi:10.2134/agronj15.0152

Received 30 Mar. 2015

Accepted 28 July 2015

Available freely online through the author-supported open access option

Copyright (c) 2015 by the American Society of Agronomy

5585 Guilford Road, Madison, WI 53711 USA

All rights reserved

\section{7 he northern Great Plains (NGP) is a net exporter of grains, livestock, poultry, and dairy prod- ucts. In 2014 South Dakota ranked fourth in U.S.} wheat (Triticum aestivum L.) production, seventh in U.S corn production, and eighth in U.S. beef calves (Bos taurus) and calf production. Due to the predicted risk of mega-droughts and high temperatures in the southern and central Great Plains (Hatfield et al., 2011; Schrag, 2011; Cook et al., 2015), it is likely that the world will increasingly depend on livestock and cereal grains produced in the NGP. To provide local, regional, and global food security, there is a continued need to develop, test, and implement sustainable systems as agricultural intensification accelerates. A critical component in testing new systems is the benchmarking of current activities.

Land-use data can be derived from National Land Cover Database (Jin et al., 2013), the cropland data layer (CDL) (Han et al., 2012), the Census of Agriculture, the National Agricultural Imaging program (Farm Service Agency, 2013), and National Agricultural Statistic Service (2015) surveys. However, these information sources produce different landuse predictions and the question arises as to which publically available information layer is most accurate (Laingen, 2015). One of the most convenient and widely used sources of information is CropScape, which allows the user to query the CDL database for specific information (Han et al., 2012; http://nassgeodata.gmu.edu/CropScape/). Even though the CDL has relatively high error in areas containing grasslands, it has been used for a variety of purposes including policy decisions and assessing land-use change (Laingen, 2015; Reitsma et al., 2015). Reitsma et al. (2015) reported that the CDL cropland producer accuracy (percentage of ground observed sites that were correctly identified) for South Dakota ranged from 89.2\% in the east-central region of the state to $42.6 \%$ in the northern region, whereas grassland producer accuracy ranged from $95.2 \%$ in the northern region to $38.9 \%$ in the southern region. These findings suggest that the CDL does not provide the desired accuracy to assess the impact of land-use change on soil sustainability. Therefore, this study examined land-use changes based

K.D. Reitsma, Encirca Services, Tea, SD 57064; S.A. Clay and D.E. Clay, Plant Science Dep., South Dakota State Univ., Brookings, SD 57007; B.H. Dunn, ABS College, South Dakota State Univ., Brookings, SD 57007; U. Mishra, Argonne National Lab., Argonne, IL 60439; and T. DeSutter, Dep. of Soil Science, North Dakota State Univ., Fargo, ND 58105. *Corresponding author (david.clay@ sdstate.edu).

Abbreviations: CDL, crop land data layer; CRP, Conservation Reserve program; LCC, land capability class; NGP, northern Great Plains; NIAP, National Agricultural Imaging Program; SOC, soil organic carbon. 
on visual identification of land use in high resolution color remote sensed images. The study's objectives were to determine the impact of land-use change on soil sustainability and discuss the factors contributing to land-use change in a climate transition zone.

\section{METHODS}

\section{Characteristics of the Model System}

The study was conducted in South Dakota between 2006 and 2012 because: (i) the area has continental climatic conditions with soil moisture regimes that range from udic (eastern edge) to aridic (western edge) and temperature regimes that range from mesic (south edge) to frigid (northern edge); (ii) spring temperatures and rainfall has increased (Schrag, 2011); (iii) the state has viable livestock, dairy, and row crop production industries that make it economically feasible to convert from grasslands to croplands and vice versa; (iv) the region provides many services to the United States that include flood mitigation and wildlife habitat; and (v) soil and climatic conditions exist that provide the opportunity to sequester C (Clay et al., 2012, 2015). The native vegetation was tall grass prairie along the eastern edge and mixed grass prairie for the remaining portion of South Dakota. Since homesteading in the 1880s, the regions large herbivore has switched from bison (Bison bison) to cattle.

The glaciated eastern region of South Dakota is composed of loess and glacial drift soils (Fig. 1), and receives most of its precipitation in the spring and fall (Clay et al., 2014). In this region, potholes, formed by receding glaciers, speckle the landscape and fill with spring melt-water, rain, and runoff. These potholes provide habitat for migrating water fowl and help mitigate flooding in the Missouri and Mississippi Rivers. The dominant rotation in eastern South Dakota is corn and soybean [Glycine $\max (\mathrm{L}$.$) Merr.] rotation, whereas in the central$ Glaciated Plains the rotations include including corn, soybean, wheat (Triticum aestivum L.), sunflower (Helianthus annuus L.), alfalfa (Medicago sativa L.), mixed forages, and proso millet (Panicum milliaceum L.).
South Dakota's western and rolling shale plain region has parent materials dominated by marine shale with the exception of the sandy and silty tablelands in Southwest South Dakota. These non-glaciated shale soils have shrink-swell clays and crop production that is often limited by low plant available water, steep slopes, and saline-sodic conditions. Farmers in this region use crop rotations that include corn, soybean, wheat, sunflower, canola (Brassica napus L.), barley (Hordeum vulgare L.), lentil (Lens culinaris Medik.), flax (Linum usitatissimum L.), and pea (Pisum sativum L.).

In the study area, no-tillage adoption increases from the east to the west across the state (Clay et al., 2012). The wide-scale adoption of no-tillage in the central and western regions of South Dakota are attributed to transgenic crops that reduced the use of tillage to control pests, the development of effective no-tillage equipment, and plant cultivars with improved water use efficiency (Lee et al., 2014; Clay et al., 2014).

\section{Assessing Land-Use Change}

High-resolution remote sensing data were obtained from the USDA Farm Service Agency and National Agricultural Imaging Program (NIAP) (Farm Service Agency, 2013) for 2006 and 2012. The delivered NIAP imagery is digitally registered, ortho-rectified, has a uniform scale, and is adjusted for topographic relief. The images had 2-m resolution in 2006 and $1-\mathrm{m}$ resolution in 2012. The NIAP data were collected during the growing season and provided information from three bands (blue, green, and red).

In 2006, 1600 random points were selected in each of the nine National Agricultural Statistics Service reporting districts in South Dakota (Fig. 1 and 2) for a total of 14,400 points. Visual classification for each 8 - by 8 -m area was accomplished by using features such as streams, crop rows, houses, roads, and field borders in the land surrounding each designated point. Each point was identified as cropland, grassland, NonAgriculture (NonAg), Non-water Habitat, and Water Habitat. Croplands were defined as cultivated crops other than hay and

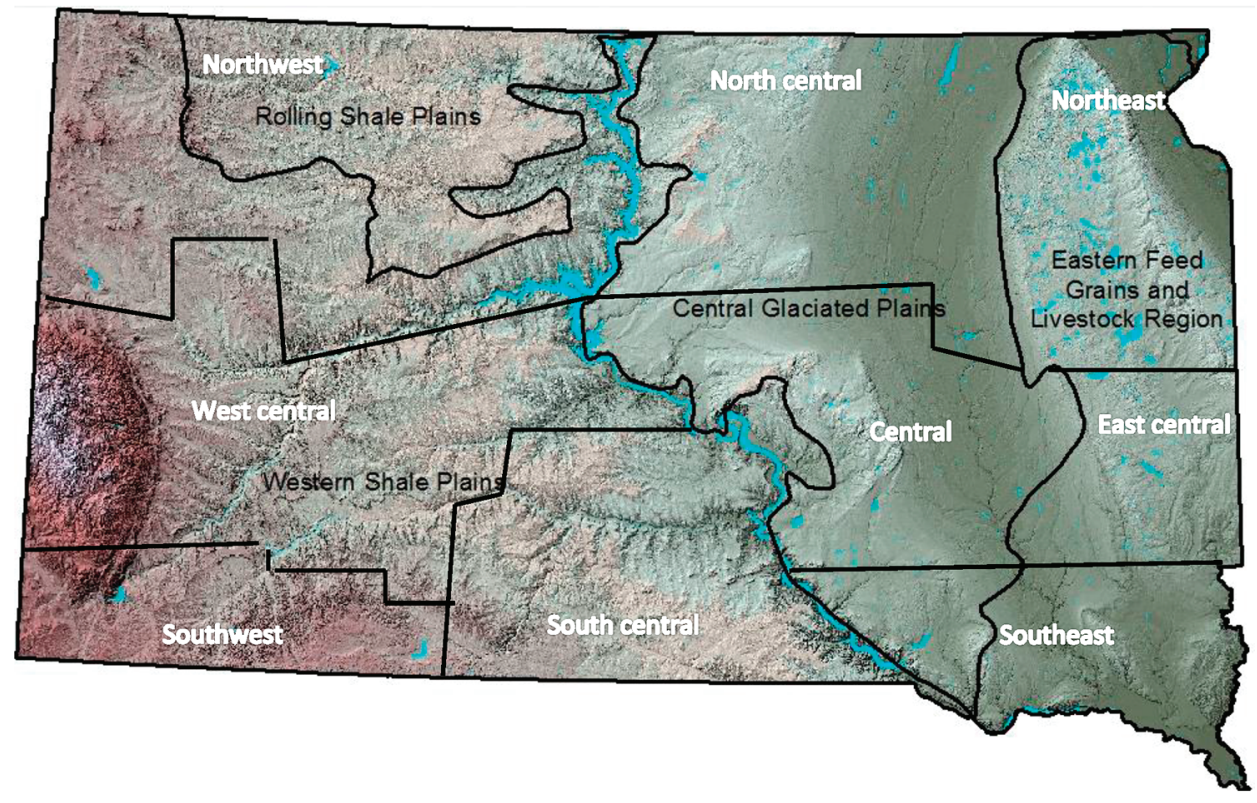

Fig. I. Generalized agro-eco regions and USDA-NASS reporting regions of South Dakota. 
alfalfa, whereas grasslands were defined as range, pasture, hay, alfalfa, and other grasslands. Non-Ag areas were defined as roads and right-aways, farmsteads, cities, and towns. Non-water habitat areas were defined as wetlands and forest, whereas water habitats were defined as open water, which consists of streams, rivers, and lakes. The identical 14,400 sampling points were visually reclassified in 2012 .

Quality control of this classification approach was conducted by randomly selecting 100 points each year for reclassification. The original and reclassified points were identical $99 \%$ of the time.

\section{Assessing Risk}

For each of the 14,400 observation points, the LCC and dominant LCC subclass values were obtained from the Soil Survey Geographic (SSURGO) data set. The LCC of each point was determined by super-imposing the sampling points over SSURGO (Soil Survey Staff, 2015), where soils with similar uses are grouped together. The LCC separates land into eight classes (Soil Conservation Service, 1961) that generally increase with restrictions in classes I through IV and from VI through VIII. Soils with LCC values from I to IV are considered suitable for row crop production if appropriate management practices are followed. Class I soils have slight limitations that impact use (Soil Conservation Service, 1961), whereas class II soils have moderate limitations. Class III and IV soils have severe and very severe limitations that impact use. Class $\mathrm{V}$ soils have minimal erosion risk but often have other factors, such as excess water, that impact their use. Class VI soils have severe limitations and are suitable for pasture, range, and forested land, whereas class VII soils have very severe limitations that make them suitable for only grazing, forest, and wildlife. Class VIII soils are suitable for wildlife, forest, water supply, and aesthetic purposes. The LCC classes are further separated into subclasses that include: (i) land where use is limited by erosion and runoff (e), (ii) land where use is restricted by excess water (w), (iii) land where use is limited by the soil (s), and (iv) land where use is limited by climatic conditions (c). The LCC is a classification approach that has been used in soil science to help identify land uses. Using concepts proposed by McBratney and Odeh (1997), we created a model for converting the LCC values to semi-quantitative values. Our basic model was to remove soils with a LCC value of $\mathrm{V}$ from the data set and to use the LCC values (I-IV and IV-VI) to identify restrictions. In both the east and west regions of the state, the LCC value was generally linked to slope. For example, 60 and $77 \%$ of the non LCC V soils were limited by erosion in the east and west regions, respectively. Following classification, our basic approach was validated by comparing the LCC values with independently determined slopes.

The LCC value for each mapping unit was defined using the following steps (NRCS, 2012). First, the mapping unit at each sampling point was identified. A mapping unit consists of a polygon containing soils with similar properties. Second, the dominant component technique was used to define mapping units classified as V (NRCS, 2012). This group of soils was treated separately from the remaining categories. For the LCC that were rated in the I through IV and VI through VII categories, the mapping unit value was the sum of the component percent multiplied by its numeric LCC value. Mapping units with values ranging from 1 to $1.5,>1.5$ to $2.5,>2.5$ to $3.5,>3.5$ to $5.5,>5.5$ to 6.5 , and $>6.5$ to 7.5 were assigned LCC values of I, II, III, IV, VI, and VII, respectively. To validate the LCC classification approach, 1600 sampling points within the north-central region were compared with slopes calculated from a 30-m resolution digital elevation model (USGS, 1999). Of these points, $20.3,52,19.3$, and $6.6 \%$ had subclass limitations of c, e, s, and w, respectively. Within the e subclass ( $52 \%$ of the points), there was a highly significant positive relationship between the LCC value and the associated slope $(\mathrm{S})[\mathrm{S}=$ $\left.2.36+1.70(\mathrm{LCC})\left(r^{2}=0.35, p<0.01\right)\right]$.

\section{Statistical Methods}

The 14,400 observation points were aggregated into two groups the eastern (NASS regions that include northeast, east central, southeast, north central, central) and western (NASS regions that include south central, northwest, west central, southwest) areas of South Dakota (Fig. 1). The eastern region had 8000 points and the western region had 6400 sampling points (Fig. 2). Based on defined land uses, four land-use change categories were compared (cropland in 2006 and 2012, grassland in 2006 and 2012, cropland in 2006 and grassland in 2012, and grassland in 2006 and cropland in 2012). Proportions were determined by dividing the number of sampling points within a land change category and LCC by the total number of points within the respective land change category. Standard errors $\left[(\text { pai }(1-\text { pai }) / n)^{0.5}\right]$ of each proportion were calculated (Wilson, 1927; Newcombe, 1998).

\section{RESULTS AND DISCUSSION}

\section{Land-Use Change in a Vegetation and Climate Transition Zone}

Over the 6 yr of the study $6.87 \%$ of the states grassland $(10,630,000 \mathrm{ha})$ were converted to croplands and $4.15 \%$ of the states croplands $(6020,000 \mathrm{ha})$ were converted to grassland (Table 1). State-wide, approximately 2.7, 29.1, 21.1, 12.9, $7.8,17.1,8.4$, and $0.5 \%$ of the observation sites occurred on soils with LCC classes of I, II, III, IV, V, VI, VII, and VIII, respectively. In eastern South Dakota, 17.8, 47.6, 14.0, and $12.5 \%$ of soils at observation points had LCC subclasses of c, e, s, and w, respectively, whereas on the western side of South Dakota 3.7, 72.9, 18.7, and 2.8\% of the observation points had LCC subclasses of c, e, s, and w, respectively. Based on point

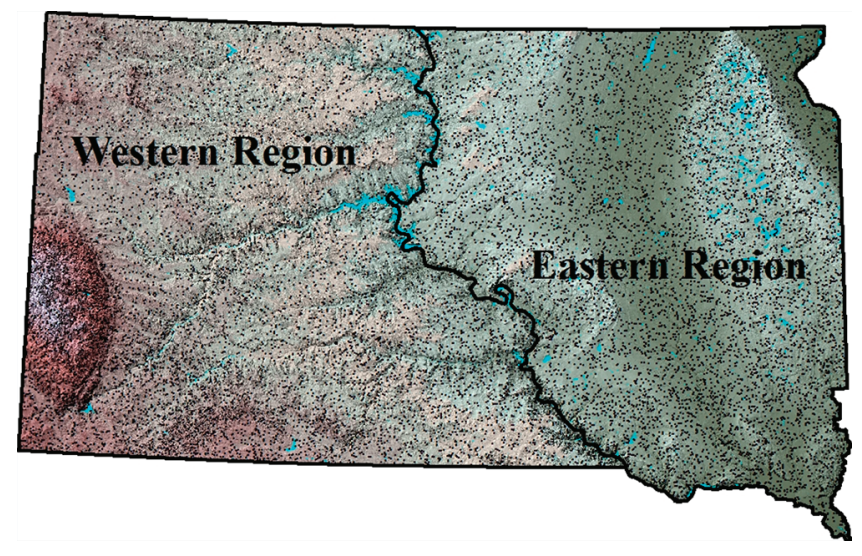

Fig. 2. Distribution of 14,400 observation points between western and eastern South Dakota. 


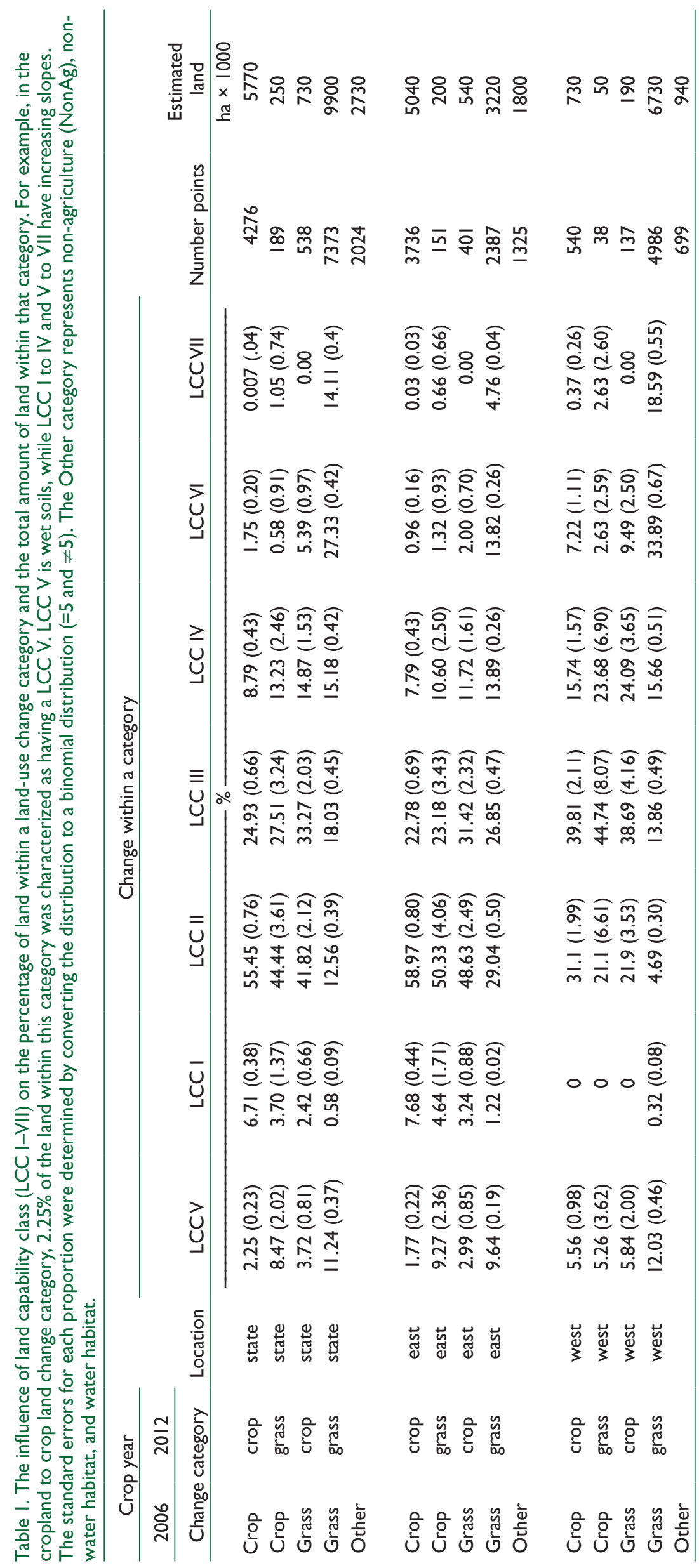


observations, the amount of non-agricultural land increased from 626,100 to 636,900 ha during the 6-yr study period.

In eastern South Dakota, 5,040,000 ha were in cropland in 2012, and 3,200,00 ha were in grassland. On 200,000 ha management changed from cropland to grassland, and on 540,000 ha management changed from grassland to cropland. The grassland to cropland category had a lower percentage of observations (20.26\%) with LCC classes of IV, VI, and VII than the grassland to grassland category (56.62\%). In addition, the grassland to cropland category had a higher percentage (77.51\%) of sampling points that were I, II, and III than the grassland to grassland category $(31.17 \%)$. The LCC averages for the cropland to cropland, cropland to grassland, grassland to cropland, and grassland to grassland categories were 2.40, 2.76, 2.68, and 3.55, respectively. Again, higher LCC values indicate more restrictions. These findings suggest that $95 \%$ of the grassland sites that were converted to cropland were suitable for crop production if appropriate management practices were adopted (LCC $£ I V)$ (Lindstrom et al., 1994).

In eastern South Dakota, the average LCC value was lower in the converted grassland (2.68) than the remaining grassland (3.55). These values suggest that grassland conversion was not random and that on average, converted grasslands had fewer restrictions than the remaining grasslands. Approximately $1.77 \%$ of the cropland to cropland category had a LCC value of $\mathrm{V}$, whereas $9.64 \%$ of the grassland to grassland category had a LCC value of V, and $9.27 \%$ of the cropland to grassland category had a LCC value of V. These findings suggest that wet soils that were cropped in 2006 were preferentially converted to grasslands. Statewide, from 2006 to 2012, 20,000 ha of cropland were converted to grassland in areas limited by excess water (LCC V).

In western South Dakota, the conversion of cropland to grassland occurred on 190,000 ha $(2.61 \%$ of the land to produce crops and grass). Approximately $2.89 \%$ of the grassland sites were converted to cropland. Of the converted sites, $5.84 \%$ had a LCC value of V. This percentage was lower than the percentage of land (12.03\%) that was in the grassland to grassland category. This finding suggests that grassland that was converted to cropland had a lower risk of excess water than the grassland to grassland category. Lower percentages of sites in the west than the east in the LCC V category suggests that excess soil wetness was a greater restriction in the east than the west. These findings are consistent with increasing precipitation from the eastern to western portions of the state.

In western South Dakota, the grassland to grassland category had a lower proportion of sites (34.5\%) that were classified as I, II, III, and IV than the grassland to cropland category (84.71\%). In addition, the grassland to grassland had a greater proportion of sites (52.48\%) within the VI and VII categories than the grassland to cropland (9.49\%) category. The LCC average for the cropland to cropland, cropland to grassland, grassland to cropland, and grassland to grassland were 3.33 , $3.32,3.42$, and 5.07, respectively, with higher values indicating more restrictions. As in eastern South Dakota, converted grasslands had lower LCC values than the remaining grasslands, which suggests that the conversion process was not random.

Our findings differ from those of Wright and Wimberly (2013). Wright and Wimberly (2013) underestimated the risk of grassland conversion for erosion and reported that between 60 and $70 \%$ of converted grassland sites occurred on LCC II land, whereas our study indicated that statewide only about $42 \%$ of grassland to cropland sites had LCC values of I and II. In addition, Wright and Wimberly (2013) implied that grasslands were converted to croplands in areas surrounding wetlands. We could not confirm this hypothesis, however, we did show that 20,000 ha were converted from cropland to grassland in areas limited by excess water (LCC V).

\section{Implications of Land-Use Change for Sustainability}

Land-use change is non-sustainable if the management practices place the soil and services provided by the soil at risk. Worldwide the dominant practices impacting sustainability are adoption of practices that do not maintain soil health and soil organic $\mathrm{C}$, do not minimize erosion, do not protect the soil from the accumulation of $\mathrm{Na}$ and other salts, and do not consider other services provided by the resource (Baumhardt et al., 2015). In South Dakota all of these factors impact sustainability (Clay et al., 2012, 2014, 2015; Cook et al., 2015; He et al., 2013, 2015). Preliminary research suggests that climate change in the region, with warmer spring temperatures and up to 130 $\mathrm{mm}$ more annual precipitation (Schrag, 2011), is one factor that can accelerate the adoption of non-sustainable practices. For example, warmer temperatures and greater rainfall provide more stable conditions for growing annual row crops, and hence, the conversion of the grassland into cropland. However, annual cropping places many soils at risk for several reasons. First, when grassland is converted to annual crops, the density of the root system is reduced. This decrease can contribute to less stable soil structure and reduced water infiltration. The second factor is that grassland conversion when combined with increased spring rainfall can contribute to a rising water table and the transport of $\mathrm{Na}$-containing salts from ancient marine sediments that underlie much of the area to the soil surface. The Na contained in these salts then destabilize the soil structure within several years (He et al., 2013, 2015). Land-use change can also impact erosion, which can be minimized by the adoption of conservation tillage practices (Lindstrom et al., 1994; Clay et al., 2012).

The South Dakota example of land-use change provided here is but a microcosm of concern. Worldwide land-use changes must be addressed. Soil erosional losses on converted lands can be staggering when conservation practices are not adopted. In Ethiopia, Fowler and Rockstram (2001) reported that the conversion of grassland to cropland may have resulted in soil loss rates as high as $290 \mathrm{Mg}(\text { ha } \times \text { year })^{-1}$, whereas in Turkey, Evrendilek et al. (2004) reported that grassland conversions increased soil erodibility by $46.2 \%$. Farms in many developing countries do not use conservation tillage practices. For example, in Africa, where land-use change is being used to promote economic development, no-tillage was utilized on only $0.3 \%$ of the farmed land between 2008 and 2009 (Maitima et al., 2009; Derpsch et al., 2010; Sanchez 2002, 2013). In addition, in Brazil land-use change is linked to subsistence farming and the production of timber, livestock, and ethanol (Müller et al., 2004; Nassar and Moreiro 2013; California Electric Transportation Coalition, 2013; Strassburg et al., 2014). 


\section{What Are the Factors Responsible for Land-Use Change in South Dakota?}

The observed land-use changes could result from many factors including: (i) the desire to increase financial returns, (ii) changes in the land ownership structure, (iii) the acceleration of the rotational sequence, (iv) technology improvements, (v) governmental policies, (vi) climate change, (vii) the combined impact of an aging workforce and labor requirements. Each of these factors is discussed below.

\section{Profitability}

Three of the most important factors influencing agricultural profitability are prices received, yield, and production costs (Janssen et al., 2013; Pflueger, 2011; Bourlion et al., 2013). Associated with an increased corn yield $\left.[135 \mathrm{~kg} \text { (ha year })^{-1}\right]$ during the study period was a $192 \%$ [(New price - old price)/old price] increase in the selling price from $2006\left(\right.$ US $\$ 89.83 \mathrm{Mg}^{-1}$ ) to $2012\left(\$ 263.20 \mathrm{Mg}^{-1}\right.$ ) (National Agricultural Statistics Service, 2014, 2015), although corn production costs also increased from $\$ 862 \mathrm{ha}^{-1}$ in 2001 to $\$ 1590 \mathrm{ha}^{-1}$ in 2012. Taking into account production costs and selling prices, there was an average $\$ 202 \mathrm{ha}^{-1}$ loss in 2001 and a $\$ 368 \mathrm{ha}^{-1}$ profit in 2012 for corn production (Pflueger, 2011; Janssen et al., 2013; National Agricultural Statistics Service, 2014). Soybean had similar changes in yield, selling price, and production costs. From 2006 to 2012, (i) average soybean yield increased by $13.3 \mathrm{~kg}$ (ha year) ${ }^{-1}$; (ii) soybean selling price increased 148\%; and (iii) production costs increased from $\$ 346 \mathrm{ha}^{-1}$ in 1989 to $\$ 842 \mathrm{ha}^{-1}$ in 2012 (Bourlion et al., 2013), with the increases in yield and selling price offsetting the production cost increases.

Cattle profitability had similar temporal variability. In South Dakota, the cow-calf enterprise is used to produce calves that are sold. In this system, cows and calves are generally grazed on pastures or range (grasslands). From 1991 to 1999 South Dakota, Wyoming, Iowa, and North Dakota ranchers realized a $\$ 33$ net annual income per beginning fiscal year female (Dunn et al., 2003). Mousel (2010) reported a 53\% decrease in profitability from 2002 to 2008 in eastern South Dakota cowcalf operations. After 2009, cow-calf operations profitability rebounded and Hansen (2013) reported that for south-central North Dakota net income increased from $\$ 37.75 /$ cow in 2008 to $\$ 188.15 /$ cow in 2012 .

This discussion indicates that net income from calf production is highly variable, and that it is difficult to directly compare these systems because grasslands generally were used on soils with lower LCC values than cropland, and that to convert the per cow values to per hectare basis the cow/calf carrying capacity is needed. These values also suggest the causes for land-use change are more complex than economics.

\section{Changing Ownership Structure}

A long-term possible threat to sustainability is a change in the farm ownership structure. Since the land was homesteaded, many land-use decisions have been made by owners or managers of multi-generational family farms. These farms have multiple goals including producing a profit, sending a son/daughter to college, and using practices that maintain the soil resource to the best of each individual farms ability so that the farm can be passed down to the next generation. Many of these family farms survived the Dust Bowl of the 1930s and have stories and photographs that have been passed down from one generation to another.

Since the 1930s the farm organizational structure has been changing gradually from an owner-operator system to a renteroperator system. Currently about $40 \%$ of U.S. farm land is rented (Nickerson et al., 2012; Janssen et al., 2013). Many rental arrangements are short-term leases that may encourage short-term returns at the expense of long-term sustainability. For example, in $201280 \%$ of the Iowa leases were 1-yr contracts (Duffy et al., 2013). Rental rates for croplands are generally higher than the rate for grasslands (Janssen et al., 2013), and with time, rented land and their non-local owners are becoming disconnected. Similar land ownership structural changes are occurring on a global scale, with investors from the United States, Europe, and Japan purchasing arable land that have water resources in Africa, South America, and Australia (Mann, 2010).

\section{Rotational Sequence}

In climate and vegetation transition zones, complex rotational sequences can be modified to improve financial returns. The NGP rotations can range from continuous corn to diverse rotations that include several years of alfalfa (Clay and Aguilar, 1998; Sainju et al., 2009). Alfalfa has several advantages including improved weed control, improved soil health, and reduced disease pressure. Grassland conversion to cropland may result from planned rotational management decisions where cropland is planted to alfalfa/grass pasture and then rotated to cropland. The decrease in grasslands from 2006 to 2012 could have been attributed to an accelerated rotational sequence, where the length of grassland was reduced from four to fewer years (Lubowski et al., 2008; Dillivan, 2014; National Agricultural Statistics Service, 2014).

\section{Technology Improvements and Industry Investments}

A factor contributing to grassland conversion to cropland is technology improvements (Clay et al., 2014; Lee et al., 2014; Mamani-Pati et al., 2014). Technology improvements were not discussed in land-use change papers by Lambin et al. (2001), Lubowski et al. (2008) and Wright and Wimberly (2013), but are major developments making row-crop production less problematic. Since the 1950s, genetic improvement and reduced-tillage planting equipment have extended corn and soybean production into increasingly drier environments (Clay et al., 2014). For example, from 1960 to 2010 corn precipitation use efficiency (PUE) increased from 90 to $200 \mathrm{~kg}(\mathrm{ha} \mathrm{cm})^{-1}$ (Clay et al., 2014). Continued improvement of PUE is likely to occur (Chang et al., 2014). In addition, the development of transgenic crops and improved no-tillage planters also contributed to the expansion of the Corn Belt westward (Lee et al., 2014). In South Dakota, the net result of these advances were: (i) a $24 \%$ increase in soil organic matter from 1985 to 2010, (ii) an improved ability of the soil to store water, (iii) enhanced crop resistance against extreme climatic events, and (iv) rapid adoption of reduced tillage systems which reduced impact of agriculture on the environment 
(Kovach et al., 1992; Clay et al., 2012, 2014; Lee et al., 2014; Smart et al., 2015).

A third technology improvement that has increased corn production areas has been the development of the ethanol industry, which reduced the gasoline selling price (Du and Hayes, 2008). In the U.S. Corn Belt, corn-ethanol production reduces the total amount of grain available for livestock feed and increases the grain selling price. However, these impacts are partially mitigated by production of distillers grain during fermentation process and the need to mix the distillers grain with low quality hay or corn stover (Babcock et al., 2008; Carlson et al., 2010; Mamani-Pati et al., 2010).

\section{Government Policies}

Government policies can simultaneously encourage and/ or discourage land-use change. One option being considered by the European Union's Common Policy Program is the creation of ecological focus areas (Oppermann et al., 2014), whereas in the United States, the Conservation Reserve program (CRP), the Sod Saver program, and the Swamp Buster program are being used to protect soil and wetland habitats. Originally, the CRP provided payments to farmers to convert highly erodible cropland to vegetative cover. In 1996 this program was modified to include wildlife benefits (Janssen et al., 2008).

The 2014 Farm Bill target for the amount of land enrolled in U.S. CRP was reduced from 14.6 million to 10.9 million ha. Since 2006, the amount of U.S. land enrolled in CRP contracts has been decreasing. For example, the amount of South Dakota land in CRP contracts decreased from 630,036 ha on February 2007 to 283,956 ha in 2014 (Farm Service Agency, 2015). Similar decreases occurred in North Dakota and Montana. A 2007 survey of South Dakota CRP contract owners supports the hypothesis that non-CRP enrollment may be partially responsible for the conversion of grassland to cropland. This survey indicated that $37 \%$ of the enrolled land in 2007 was not likely to be re-enrolled. Of the land not re-enrolled, the survey respondents indicated that $53.8 \%$ would likely be placed into row crops, $6.9 \%$ would be seeded to alfalfa, and $30 \%$ would remain in grass and used for grazing (Janssen et al., 2008).

The Sod Saver program was designed to prevent farmers from purchasing crop insurance for the first $5 \mathrm{yr}$ following the conversion of a native prairie to row crop production (Claassen et al., 2011). However, the Sod Saver provision was never enforced because it required authorization by the state's governor. Claassen et al. (2011) estimated that if enacted, the Sod Saver provision would have reduced rangeland to cropland conversion by $0.9 \%$. However, it also would have reduced crop revenues by $5 \%$ and net returns by $14 \%$. In the 2014 Farm Bill, the Sod Saver program did not require authorization by the governors of Montana, North Dakota, South Dakota, Minnesota, Iowa, and Nebraska and will reduce the insurance subsidy for plowed native prairies by $50 \%$.

The Highly Erodible Land Conservation and Wetland Conservation Compliance (Swamp Buster) program was designed to remove incentives for producing agricultural commodities on wetlands and highly erodible lands. This program has greatly reduced wetland conversion to agricultural production. Other government programs that indirectly impact land-use include crop insurance (Claassen et al., 2011), inheritance laws, and property taxes.

\section{Climate Change}

Climate change complicates food production and land use by at least four mechanisms (Hatfield et al., 2011). The first mechanism is higher temperatures, which depending on the location, can increase or decrease yields (Hatfield et al., 2011). In the northern Great Plains, higher temperatures are lengthening the growing season, which in turn reduce the risk of growing annual crops (Schrag, 2011).

The second mechanism is altered precipitation patterns. The northern Great Plains has a history of high precipitation variability, which is projected to increase (Schrag, 2011; Clay et al., 2014). Higher spring rainfall when combined with technology improvements, provide an economic opportunity for farmers to increase their agricultural intensity (Schrag, 2011). The third mechanism is that elevated $\mathrm{CO}_{2}$ levels may increase the water-use efficiency and productivity of NGP plants (van der Steen et al., 2015). The fourth mechanism is that extreme climatic events (e.g., drought and fall blizzards) that reduce herd sizes can adversely affect the livestock industry for several years.

\section{An Aging Workforce and Labor Requirements}

Another factor influencing land-use change is the increasing average age of ranchers and farmers. From 2002 to 2012 the average age of U.S. farmers and ranchers increased from 55.3 to $58.3 \mathrm{yr}$. Associated with the aging of the workforce might be downsizing the operations as farmers and ranchers move toward retirement. In this process, grazing lands may be preferentially transferred to croplands to reduce some of the workload associated with animal production.

\section{SUMMARY}

Worldwide pressures to increase food production in a changing climate create jobs in rural communities, and increase financial returns and will contribute to land-use changes and agricultural intensification in northern environments (Lambin et al., 2001; Lubowski et al., 2008; Vega et al., 2009; Cook et al., 2015). This study investigated the sustainability of land-use change in a climate-vegetation transition zone.

Land-use change can be unsustainable if change occurs on land not suited for crop production. For example, research suggests that grassland to cropland conversion may not be sustainable on the regions saline/sodic soils. Over this 6-yr study, 6.8\% of the grasslands $(726,000 \mathrm{ha})$ were converted to cropland, with $93 \%$ occurring on lands generally considered suitable for crop production (LCC $\leq$ IV) if appropriate practices are followed. Converted grassland, however, had higher LCC values than existing croplands and lower LCC values than remaining grasslands. In addition, $4.2 \%$ of the croplands (255,000 ha) were converted to grasslands, and statewide, 20,000 ha of cropland were converted to grasslands in areas limited by excess water (LCC V).

Our assessment suggested that land-use changes from 2006 to 2012 were likely linked to several factors including a desire to increase financial returns, government policies, climate 
change, a changing ownership structure, improved technology, and an aging workforce (Lambin et al., 2001; Lubowski et al., 2008; Schrag, 2011; Turner, 2014). For long-term agroecosystem sustainability and improved stewardship, research and outreach programs must reach audiences that include landlords and policymakers and provide balanced information about the goods and services of different land uses and not just the economic gains (Jackson and Jackson, 2002; Derpsch et al., 2010; Bich et al., 2014; Reese et al., 2014; Clay et al., 2015).

\section{ACKNOWLEDGMENTS}

Funding was provided by South Dakota State University, Brookings, SD, and USDA-NRCS-CIG Grants 69-3A75-12-185 and $11-174$.

\section{REFERENCES}

Babcock, B.A., D.J. Hayes, and J.D. Lawrence. 2008. Using distiller's grains in the U.S. and international livestock and poultry industries. Midwest Agribusiness Trade Research and Information Center. http://www.card.iastate.edu/books/distillers_grains/ pdfs/distillers_grains_book.pdf. (accessed 17 Mar. 2015).

Baumhardt, R.L., B.A. Stewart, and U.V. Sainhju. 2015. North America soil degradation: Processes practices and mitigation strategies. Sustainability 7:2936-2960. doi:10.3390/su7032936

Bich, A.D., C.L. Reese, A.C. Kennedy, D.E. Clay, and S. A. Clay. 2014. Corn yield is not reduced by in-season cover crop seeded after the weed free period. www.plantmanagementnetwork.org/ $\mathrm{cm} /$. Crop Manage. doi:10.2134/CM-2014-0009-RS (accessed 17 Mar. 15).

Bourlion, N., L. Janssen, and D. Guthmiller. 2013. Chapter 56: Soybean production costs. In: D.E. Clay, C.G. Carlson, S.A. Clay, L. Wagner, D. Deneke, and C. Hay, editors, iGROW Soybean: Best management practices. South Dakota State Univ., Brookings.

California Electric Transportation Coalition. 2013. California low carbon fuel standard, compliance outlook for 2020. http://www. ceres.org/resources/reports/california2019s-low-carbon-fuelstandard-compliance-outlook-for-2020 (accessed 17 Mar. 2015).

Carlson, C.G., D.E. Clay, C. Wright, and K.D. Reitsma. 2010. Potential impacts of linking ethanol, crop production, and backgrounding calves on economics, carbon, and nutrient budgets. South Dakota State Univ. Ext. Publication, Brookings. http:// pubstorage.sdstate.edu/AgBio_Publications/articles/exex8165. pdf (accessed 28 Aug. 2015).

Chang, J., D.E. Clay, S.A. Hansen, S.A. Clay, and T. Schumacher. 2014. Water stress impacts on transgenic corn in the northern Great Plains. Agron. J. 106:125-130. doi:10.2134/agronj2013.0076

Claassen, R., F. Carriazo, J.C. Cooper, D. Hellestein, and K. Veda. 2011. Grassland to cropland conversion in the Northern Plains. ERRN 120. USDA Economic Res. Serv. http://www.ers.usda. gov/media/128019/err120.pdf (accessed 17 Mar. 2015).

Clay, S.A., and I. Aguilar. 1998. Weed seedbank and corn growth following continuous corn or alfalfa. Agron. J. 90:813-818. doi:10.2134/agronj1998.00021962009000060016x

Clay, D.E., J. Chang, S.A. Clay, J. Stone, R. Gelderman, C.G. Carlson, K. Reitsma, M. Jones, L. Janssen, and T. Schumacher. 2012. Yield increases and no-tillage adoption impacts on carbon sequestration and associated footprint. Agron. J. 104:763-770. doi:10.2134/agronj2011.0353

Clay, D., S. Clay, K. Reitsma, B. Dunn, A. Smart, G. Carlson, D. Horvath, and J. Stone. 2014. Does the conversion of grasslands to row crop production in semi-arid areas threaten global food security? Global Food Security. http://www.sciencedirect.com/science/ journal/22119124/3 (accessed 28 Aug. 2015)
Clay, D.E., G. Reicks, C.G. Carlson, J. Miller, J.J. Stone, and S.A. Clay. 2015. Residue harvesting and yield zone impacts $C$ storage in a continuous corn rotation. J. Environ. Qual. 44:803-809. doi:102134/jeq2014.070322

Cook, B.I., T.R. Ault, and J.E. Smerdon. 2015. Unprecedented 21st century drought risks in the American south west and central plains. Sci. Advances 1:e1400081. doi:10.1126/sciadv.1400082

Derpsch, R., T. Friedrich, H. Kassam, and L. Hongwen. 2010. Current status of adoption of no-tillage farming the world and some of its main benefits. Int. J. Agric. Biol. Eng. 3:1. doi: 10.3965/j. issn.1934-6344.2010.01.0-0

Dillivan, K. 2014. South Dakota alfalfa hay supply and demand effect price. South Dakota State Univ., iGrow. http://igrow.org/livestock/profit-tips/south-dakota-alfalfa-hay-supply-and-demandaffect-price/ (accessed 17 Mar. 2015).

Du, X., and D.J. Hayes. 2008. The impact of ethanol production on U.S. regional prices and the profitability of U.S. oil refinery industry. Center for Agriculture and Rural Development. Iowa State Univ. Working Paper 08-wp 467. http://www.card.iastate. edu/publications/DBS/PDFFiles/08wp467.pdf (accessed 17 Mar. 2015).

Duffy, M., W. Edwards, and A. Johanns. 2013. Survey of Iowa leasing practices. Ag Decision Maker, C2-15. Iowa Ext. Serv., Ames.http:// www.leopold.iastate.edu/news/03-02-2011/sustainable-agriculture-land-tenure-project-iowa-farmland (accessed 10 Mar. 15).

Dunn, B., E. Hamilton, and D. Pruitt. 2003. Characterization of the beef cow-calf enterprise of the northern Great Plains. SD Extension Beef 2003-09. https://www.sdstate.edu/ars/species/beef/ beef-reports/upload/2003-09-Characterization-of-the-BeefCow-calf-Enterprise-of-the-Northern-Great-Plains.pdf (accessed 17 Mar. 15).

Evrendilek, F., I. Celik, and S. Kilic. 2004. Changes in soil organic carbon and other physical soil properties along adjacent Mediterranean forest, grassland, and crop ecosystems in Turkey. J. Arid Environ. 59:743-752. doi:10.1016/j.jaridenv.2004.03.002

Farm Service Agency. 2013. National Agriculture Imagery Program (NAIP). USDA-FSA, Washington, DC. http://fsa.usda.gov/ FSA/apfoapp $?$ are $=$ home $\&$ subject $=$ prog\& topic $=$ nai $($ accessed 28 Apr. 2014).

Farm Service Agency. 2015. CRP enrollment and rental rates by state, 1986-2014. USDA-FSA, Washington, DC. http://www.fsa. usda.gov/FSA/webapp?area $=$ home\&subject $=$ copr\& topic $=$ crpst (access 10 Mar. 15).

Fowler, R., and J. Rockstram. 2001. Conservation tillage for sustainable agriculture: An agrarian revolution gathers momentum in Africa. Soil Tillage Res. 61:93-108. doi:10.1016/ S0167-1987(01)00181-7

Han, W., Z. Yang, L. Di, and R. Mueller. 2012. CropScape: A web service based application for exploring and disseminating US continuous geospatial cropland data products for decision support. Comput. Electron. Agric. 84:111-123. doi:10.1016/j. compag.2012.03.005

Hansen, J. 2013. 2013 Beef production income and expenses from South Central North Dakota from 2008 to 2012. North Dakota Ext. http://www.ag.ndsu.edu/CarringtonREC/documents/livestockrd/docs2013/2013-beef-production-incomes-and-expensesfor-south-central-north-dakota/view (accessed 17 Mar. 15).

Hatfield, J.L., K.J. Boote, B.A. Kimball, L.H. Ziska, B.C. Izauralde, D. Ort, A.M. Thomson, and D. Wolfe. 2011. Climate impacts on agriculture implications of crop production. Agron. J. 103:351370. doi:10.2134/agronj2010.0303

He, Y., T.M. DeSutter, and D.E. Clay. 2013. Dispersion of pure clay minerals as influenced by calcium/magnesium ratios, sodium adsorption ratios, and electrical conductivity. Soil Sci. Soc. Am. J. 77:2014-2019 doi:10.2136/sssaj2013.05.0206n 
He, Y., T.M. DeSutter, and D.E. Clay. 2015. The relationship between SAR1:5 and SARe of three extraction methods. Soil Sci. Soc. Am. J. 79:681-687. doi:10.2136/sssaj2014.09.0384

Jackson, D.L., and L.L. Jackson, editors. 2002. The farm as natural habitat: Reconnecting food systems with ecosystems. Island Press, Washington, DC.

Janssen, L., N. Klein, G. Taylor, E. Opoku, and M. Holleck. 2008. Conservation reserve program in South Dakota: Major findings from 2007 survey of South Dakota CRP respondents. Economics research report 2008. South Dakota State Univ. http://ageconsearch.umn.edu/bitstream/37936/2/CRP2008.pdf (accessed 17 Mar. 15).

Janssen, L., B. Pflueger, and B. McMurtry. 2013. Agriculture land market trends 1991-2013. South Dakota State Univ. 03-7007-2013. http://igrow.org/up/resources/03-7007-2013.pdf (accessed 17 Mar. 15).

Jin, S., L. Yang, P. Danielson, C. Homer, J. Fry, and G. Xian. 2013. A comprehensive change detection method for updating the National Land Cover Database to circa 2011. Remote Sens. Environ. 132:159-175. doi:10.1016/j.rse.2013.01.012

Kovach, J., C. Petzoldt, J. Degni, and J. Tette. 1992. A method to measure the environmental impact of pesticides. New York Food and Life Sciences Bull. 139. New York State IPM Program, Cornell Univ., Geneva, NY. http://nysipm.cornell.edu/publications/eiq (accessed 8 Sept. 2010).

Laingen, C. 2015. Measuring cropland change: A cautionary tale. Papers Applied Geography 1:65-72. doi:10.1080/23754931.20 15.1009305

Lambin, E.F., B.L. Turner, J.G. Helmut, S.B. Agbola, A. Angelsen, J.W. Bruce et al. 2001. The causes of land-use and land-cover change: Moving beyond the myths. Glob. Environ. Change 11:261-269. doi:10.1016/S0959-3780(01)00007-3

Lee, S., D.E. Clay, and S.A. Clay. 2014. Conservation tillage and genetically modified herbicide tolerant corn (Zea mays), soybean (Glycine max), and cotton (Gossypium hirsutum): Adoption linked impacts on the environment and economic returns. In: D.D. Songstad, J.L. Hatfield and D.T. Tomes, editors, Convergence of Food Security, Energy Security and Sustainable Agriculture. Springer-Verlag, Berlin. p. 211-236.

Lindstrom, M.J., T.E. Schumacher, , and N.L. Blecha. 1994. Management consideration for returning CRP land to crop production. J. Soil Water Conserv. 49:420-425.

Lubowski, R.N., A.J. Planting, and R.N. Stravins. 2008. What drives land-use change in the United States? A national analysis of landowners decisions. Land Econ. 84:529-550. doi:10.3368/ le.84.4.529

Maitima, J.M., S.M. Mugatha, R.S. Reid, L.N. Gachimbi, A. Majule, H. Lyaruu, D. Pomery, S. Mathai, and S. Mugisha. 2009. The linkages between land-use change, land degradation and biodiversity across East Africa. African J. Environ Sci. Tech. 3:310-325.

Mann, H. 2010. Foreign land purchases for agriculture: What impact on sustainable development. United Nations Brief no. 8. http:// www.un.org/esa/dsd/resources/res_pdfs/publications/ib/no8. pdf (accessed 10 Mar. 15).

Mamani-Pati, F., D.E. Clay, and H. Smeltekop. 2014. Modern landscape management in the Andean Highlands using technology developed by the Inca Empire. In: G.J. Churcham, and E.R. Landa, editors, The soil underfoot: Infinite possibilities for a finite resource. CRC Press, Boca Raton, FL.

Mamani-Pati, E.M., D.E. Clay, C.G. Carlson, and S.A. Clay. 2010. Calculating soil organic carbon maintenance using stable and isotopic approaches: A review. In: E. Lichtfouse, editor, Sustainable agricultural reviews: Sociology, organic farming, climate change and soil science. Springer, New York. p. 189-216.
McBratney, A.B., and O.A. Odeh. 1997. Application of fuzzy set in soil science: Fuzzy logic, fuzzy measurements, and fuzzy decisions. Geoderma 77:85-113. doi:10.1016/S0016-7061(97)00017-7

Mousel, E.M. 2010. IPM-SPA:Trend analysis 2002-2008. South Dakota Ext., Beef 2010-14. http://www.sdstate.edu/ars/species/ beef/beef-reports/upload/Beef_2010-14_Mousel-2002-2008. pdf (accessed 17 Mar. 15).

Müller, M.M., M.F. Guimaraes, T. Desjardins, and D. Mitja. 2004. The relationship between pature degredation and soil properties in the Brazilian Amazon. A case study. Agric. Ecosyst. Environ. 103:279-288. doi:10.1016/j.agee.2003.12.003

Nassar, A.M., and M. Moreiro. 2013. Evidence of sugarcane expansion and expansion and agriculture land-use changes in Brazil. Inst. for Int. Trade Negotiations. http://sugarcane.org/resourcelibrary/studies/evidences_on_sugarcane_expansion_and_agricultural_land_use_changes_in_brazil_1206.pdf (accessed 17 Mar. 2015).

National Agricultural Statistics Service. 2014. Northern Great Plains. NASS, Washington, DC http://www.ers.usda.gov/data-products/commodity-costs-and-returns.aspx (accessed 17 Mar. 2015).

National Agricultural Statistics Service. 2015. Research survey data census. NASS, Washington, DC. http://www.nass.usda.gov/ (accessed 15 Mar. 2015).

Newcombe, R.G. 1998. Interval estimation for the difference between independent proportions: Comparison of eleven methods. Stat. Med. 17:873-890. doi:10.1002/(SICI)10970258(19980430)17:8<873::AID-SIM779>3.0.CO;2-I

Nickerson, C., M. Morehart, T. Kuethe, J. Beckman, J. Ifft, and R. Williams. 2012. Trends in U.S. Farmland values and ownership. EIB92. USDA Econ Res. Serv., Washington, DC. http://www.ers. usda.gov/media/377487/eib92_2_.pdf (accessed 17 Mar. 2015).

NRCS. 2012. SSURGO data packaging and use. NRCS-USDA.. http://www.nrcs.usda.gov/wps/portal/nrcs/detail/soils/survey/ geo/?cid=nrcs142p2_053631 (accessed 1 June 2015).

Oppermann, R., J. Gelhsusen, B. Matzdorf, M. Reutter, and R. Luick. S. Stein. 2014. Common agricultural policy from 2014 perspective for more diversity and environmental benefits of farming. Bimdesant fur Natyurschutz. https://www.bfn.de/fileadmin/ MDB/documents/themen/landwirtschaft/CAPEnvironmentstudy-results-nov2012en_Fin.pdf (accessed 17 Mar. 2015).

Pflueger, B. 2011. Percentage of South Dakota agricultural land operated under a rental agreement. ExEx 5080. South Dakota State Univ. http://pubstorage.sdstate.edu/AgBio_Publications/articles/ExEx5080.pdf (accessed 17 Mar. 2015).

Reese, C., D.E. Clay, S.A. Clay, A. Bich, A. Kennedy, S. Hansen, and J. Miller. 2014. Wintercover crops impact on corn production in semi-arid regions. Agron. J. 106:1479-1488. doi:10.2134/ agronj13.0540

Reitsma, K.D., D.E. Clay, B.W. Dunn, D.D. Malo, and S.A. Clay. 2015. Are digital land-use and soil databases accurate for benchmarks? Soil Sci. Soc. J. (In press.)

Sainju, U., A.W. Lenssen, T. Laesar-TonThat, and R.G. Evan. 2009. Dryland crop yields and soil organic matter as influenced by long-term tillage and cropping sequence. Agron. J. 101:243-251. doi:10.2134/agronj2008.0080x

Sanchez, P.A. 2002. Soil fertility and hunger in Africa. Science (Washington, DC) 295:2019-2020. doi:10.1126/science.1065256

Sanchez, P.A. 2013. Can the world feed itself? Some agronomic innovations. ASA Plenary Address, York Lecture. American Society of Agronomy National Meeting, Tampa, FL. 3-6 November. ASA, Madison, WI. 
Schrag, A.M. 2011. Addendum: Climate change impacts and adaptation strategies. In: S.C. Forrest, H. Stand, W.H. Haskins, C. Freese, J. Proctor, and E. Dinerstein, editors, Ocean of grass: A conservation assessment for the Northern Plains Conservation Network and Northern Great Plains Ecoregion. World Wildlife Fund-US, Bozeman, MT. http://kresge.org/sites/default/ files/Uploaded\%20Docs/WW F\%20-\%20Ocean_Grass.pdf (accessed 17 Mar. 15).

Smart, A.J., D.E. Clay, R.G. Stover, M.R. Parvez, K.D. Reitsma, and L.L. Janssen. N.H, Troelstrup, S.R. Burkhard, and E.M. Mousel. 2015. Persistence wins: Long-term agricultural conservation outreach pays off. J. Extension. 53:2R1B6.

Soil Conservation Service. 1961. Land capability classification. Agric. Handb. 210. USDA-Soil Conserv. Serv., Washington, DC. http://www.nrcs.usda.gov/Internet/FSE_DOCUMENTS/ nrcs142p2_052290.pdf (accessed March 2015).

Soil Survey Staff. 2015. Web soil survey. Natl. Soil Surv. Ctr., Lincoln, NE. http://websoilsurvey.nrcs.usda.gov/ (accessed March 2015).

Strassburg, B.B., A.E. Latawiec, L.G. Barioni, C.A. Nobre, V.P da Silva, J.F. Valentim, M. Vianna, and E.D. Assad. 2014. When enough should be enough: Improving the use of current agricultural lands could meet the production demand and spare natural habitat in Brazil. Global Climate Change 28:84-97.
Turner, B.L. 2014. To plow or not to plow: An investigation into landuse changes and consequences in the northern Great Plains using systems thinking and dynamics. Ph.D. diss. South Dakota State Univ., Brookings.

USGS. 1999. South Dakota 1 arc second (30m) digital elevation model (DEM). National Elevation Dataset. USGS EROS Data Ctr., Sioux Falls, SD. http://ned.usgs.gov/ (accessed 4 Dec. 2014).

van der Steen, P., P. Groendijk, M. Vlam, N.P.R. Duten, A. Boom, F. Bongers, T.L. Pons, G. Terburg, and P.A. Zuidema. 2015. No growth stimulation of tropical trees by 18 years of $\mathrm{CO}_{2}$ fertilization but water use efficiency increased. Nat. Geosci. 8:24-28. doi:10.1038/ngeo2313

Vega, E., G. Baldi, E.G. Jobbagy, and J. Parvelo. 2009. Land-use change patterns in the Rio de la Plata grassland: The influence of phytogeographic and political boundaries. Agric. Ecosyst. Environ. 134:287-292. doi:10.1016/j.agee.2009.07.011

Wilson, E.B. 1927. Probable inference, the law of succession, and statistical inference. J. Am. Stat. Assoc. 22:209-212. doi:10.1080/0 1621459.1927 .10502953

Wright, C. K., and M.C. Wimberly. 2013. Recent land-use change in the Western Corn Belt threatens grasslands and wetlands. Proc. National Acad. Sci. United States 110:4134-4139. doi:10.1073 